\title{
CONHECIMENTO E PARTICIPAÇÃO NAS RAZÕES ETERNAS EM TOMÁS DE AQUINO: DUAS LEITURAS *
}

Knowledge and participation in the eternal reasons in Aquinas: two readings

Luís Carlos Silva de Sousa **

Resumo: $\mathrm{O}$ artigo analisa duas leituras sobre o papel da noção de participação em nosso conhecimento das razões eternas de Deus, de acordo com Tomás de Aquino. $\mathrm{O}$ texto parte da noção de participação presente na Summa theologiae (STh. Ia q. 84, a. 5) e depois se confronta com as leituras de Cornelio Fabro e Lima Vaz. Ambos admitem uma via platonica constitutiva da noção de participação para nosso acesso às razões eternas. Argumenta-se que a leitura de Lima Vaz alcança uma maior inteligibilidade da postura de Tomás de Aquino ao repensar a própria estrutura metódica da metafísica. Lima Vaz, ao contrário de Fabro, reconhece um círculo de compreensão do Absoluto que permaneceu irrefletido em Tomás de Aquino. Por fim, são extraídas algumas consequências de um breve confronto com as duas leituras, na tentativa de propor uma perspectiva hermenêutica na dialética da participação.

Palavras-chave: Conhecimento. Metafísica. Participação. Tomás de Aquino. Deus.

Abstract: The article analyzes two readings on the role played by the notion of participation in our knowledge of God's eternal reasons, according to Thomas Aquinas. First, it examines the notion of participation in Summa theologiae (STH, Ia, 84, a, 5). It then compares the readings of Cornelio Fabro and Lima Vaz. Both admit a via platonica constitutive of the notion of participation and access to

\footnotetext{
* Artigo recebido em 20/06/2018 e aprovado para publicação em 18/05/20.

** Doutor em Filosofia pela PUC-SP. Professor efetivo da Universidade da Integração Internacional da Lusofonia Afro-Brasileira (UNILAB), em Redenção-CE, e pesquisador em Filosofia Medieval (UFC). Professor permanente externo no programa de Pós-Graduação em Filosofia na UFC.
} 
eternal reasons. It is argued that Lima Vaz's reading, by rethinking the methodical structure of metaphysics, is more intelligible when it comes to understanding Thomas Aquinas' position. Vaz, unlike Fabro, recognizes a circle of understanding of the Absolute, unreflected in Thomas Aquinas. Finally, a hermeneutical perspective in the dialectic of participation is proposed by selecting some of the consequences of this brief comparison between the two readings.

Keywords: Knowledge. Metaphysics. Participation. Thomas Aquinas. God.

\section{Introdução}

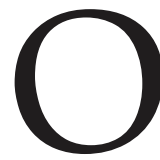
objetivo deste artigo consiste em analisar duas estratégias de leitura sobre o papel da noção de participação em nosso conhecimento das razões eternas segundo Tomás de Aquino ${ }^{1}$. $\mathrm{O}$ texto básico a ser examinado é o seguinte: STh. Ia, q. 84, a. 5. Nossa própria análise do texto de Tomás de Aquino será confrontada com as duas leituras. O fio condutor da análise consiste na comparação entre as interpretações de Cornelio Fabro (1911-1995) e Henrique Cláudio de Lima Vaz (1921-2002) sobre o papel da noção de participação a partir de uma análise do artigo 5․: "Se a alma intelectiva conhece as coisas materiais nas razões eternas" 2 . As questões que orientam a exposição são as seguintes: (a) como Tomás

\footnotetext{
${ }^{1}$ Utilizaremos as seguintes edições dos textos de Tomás de Aquino, (1224/1225-1274): Summa theologiae. Opera Omnia IV-XII (ed. Leon.), Rome 1888-1906 [S.Th.]; Quaestiones disputatae de potentia. Cura et studio P. M. Pession. Turin; Rom: Marietti, 1953 [De pot.]; Quaestiones disputatae de veritate. Opera Omnia XXII, 1-3 (Ed. Leon.), Rome 1970-1976 [De Veritate]; In librum Beati Dionysii De divinis nominibus expositio. Ed. Carla Pera, Turin 1950 [In de div. nom.]; "Corpus Thomisticum", Subsidia studii ab Enrique Alarcón collecta et edita Pampilonae ad Universitatis Studiorum Navarrensis aedes A.D. MMV. As traduções da Summa theologiae utilizadas neste artigo são as seguintes: Suma de Teologia, Primeira Parte - Questões 84-89. Tradução e Introdução: Carlos Arthur Ribeiro do Nascimento, Uberlândia: EDUFU, 2006; Suma teológica, Volume II, Parte I, Questões 44-119, São Paulo: Loyola, 2002; Os textos de Lima Vaz, fontes da pesquisa, são: LIMA VAZ, Henrique C. de. Escritos de Filosofia III: Filosofia e cultura. São Paulo: Ed. Loyola, 1997 [EF III: FC]; Escritos de Filosofia VI: Ontologia e História, São Paulo: Ed Loyola, 2001 [EF: OH]; Escritos de Filosofia VII: Raízes da Modernidade. $2^{\text {a }}$ ed. São Paulo: Ed. Loyola, 2012 [EF: RM]; Antropologia Filosófica I. São Paulo: Ed. Loyola, 1991 [AF I]; "Tópicos para uma metafísica do conhecimento". In: ULLMAN, Reinholdo Aloysio (Org.). Consecratio mundi (Festchrift) em homenagem a Urbano Zilles. Porto Alegre: EDIPUCRS, 1998 [TMC]; "Método e Dialética". In: BRITO, Emídio Fontenele \& CHANG Luiz Harding (Orgs.) Filosofia e Método. São Paulo: Ed. Loyola, 2002 [MD]. Os textos de Cornelio Fabro são os seguintes: La Nozione Metafisica di Partecipazione secondo S. Tommaso d'Aquino. Torino: Editrice, 2. ed., 1950 [NMP]; Participazione e Causalità secondo S. Tommaso d'Aquino. Torino: Editrice, 1960 [PC]; La Svolta Antropológica di Karl Rahner. Milano: Rusconi Editore, 1974 [SA]; "The Intensive Hermeneutics of Thomistic Philosophy: The notion of participation". In: The Review of Metaphysics 27 (1974), p. 449-491[IH]. Obras de outros autores, que são citadas ocasionalmente, como literatura secundária, são identificadas em notas de rodapé com referência bibliográfica completa para a primeira citação.

${ }^{2}$ STh. Ia, q. 84, a. 5. Cf. também STh. Ia, q. 12, a. 2 ad 3; q. 10 a. 6 ad 6; a. 8.
} 
de Aquino repensa nosso acesso às "razões eternas" a partir da análise do conhecimento intelectual humano? (b) qual o papel da noção de participação em nosso conhecimento das razões eternas? O interesse histórico sobre como Tomás de Aquino, em linhas gerais, busca compatibilizar Agostinho e Aristóteles no que se refere a esses problemas específicos, será ampliado do ponto de vista teórico por um confronto com as duas leituras acerca do texto da Summa theologiae. Cornelio Fabro e Lima Vaz têm em comum a perspectiva de pensar a via platônica da noção metafísica de participação em Tomás de Aquino como parte constitutiva da concepção de esse (como actus essendi), através de diferentes estratégias de interpretação sobre o processo intelectual humano de acesso às razões eternas de Deus. No que se refere a uma comparação crítica acerca das duas estratégias, argumentaremos que há razões históricas (o papel central do juízo negativo para a afirmação do ser) e teóricas (a pré-compreensão do Absoluto) para optarmos pela leitura de Lima Vaz: ela traz uma maior inteligibilidade à concepção metafísica de participação em Tomás de Aquino, sobretudo ao repensar a própria estrutura metódica de nosso acesso às razões eternas. Mas nossa própria avaliação do texto de Tomás de Aquino - e, também, no breve confronto com as duas leituras - recorre a uma perspectiva que chamaremos "especulativo-hermenêutica", ao acentuar um "círculo" de compreensão do Absoluto que permaneceu impensado em Tomás de Aquino ${ }^{3}$.

O texto está dividido em três partes. A primeira parte, "Conhecimento e participação" trata da relação entre o conhecimento intelectual humano e a noção metafísica de participação. Esta primeira parte está subdividida em duas seções: a primeira seção trata do artigo $5^{\underline{0}}$ da questão $84^{\underline{a}}$ da Suma de Teologia de um ponto de vista mais estritamente histórico, situando a epistemologia de Tomás de Aquino diante de Agostinho, ao tratar do conhecimento das coisas materiais nas razões eternas (seção 1.1). A segunda seção introduz uma discussão sobre o dinamismo transcendental do espírito inscrita em

\footnotetext{
${ }^{3}$ Por "perspectiva especulativo-hermenêutica" entendemos, primeiro, o que foi parcialmente desenvolvido por M. Heidegger em "Ser e Tempo" (Sein und Zeit, 1927), mas também, e de forma mais próxima a nossa própria leitura, o que Emerich Coreth propôs como reflexão transcendental-metafísica, ampliando assim em caráter programático o horizonte metafísico de compreensão do sentido de ser, de tal modo a compatibilizar metafísica e hermenêutica filosófica. Consideramos que há, em Coreth, uma transformação do "tomismo transcendental" na direção de uma metafísica sistemática do Ser. Isto ocorre, sobretudo, em seus últimos escritos, quando os problemas metafísicos foram rearticulados sob uma determinada perspectiva especulativo-hermenêutica (embora tal rearticulação permaneça sem maior desenvolvimento sistemático). Os pressupostos teóricos para esta interpretação encontram-se, em linhas gerais, no confronto que propomos a partir de CORETH, Emerich. Metaphysik: Eine methodisch-systematische Grundlegung. 2a Auf. Innsbruck, 1964, p. 289-321; Gottesfrage Heute. Münster: Verlag Butzon \& Bercker, 1969; Grundfragen der Hermeneutik. Freiburg im Breisgau: Verlag Herder, 1969 (Trad. br: Questões Fundamentais de Hermenêutica. São Paulo: E.P.U., 1973, p. 46; Was ist der Mensch? Grundzüge einer philosophischen Anthropologie. TyroliaVerlag Innsbruk, 1976.
} 
nossa análise do artigo $5^{\circ}$, de acordo com uma perspectiva hermenêutica própria (seção 1.2), e levanta pressupostos para a posterior exposição das duas leituras. Esta segunda parte do trabalho, "Duas leituras sobre o papel da noção de participação nas razões eternas", apresenta o cerne da discussão ao analisar traços fundamentais nas leituras de Fabro e Lima Vaz sobre a noção de participação, em sua conexão com o tópico das razões eternas (seção 2). Esta segunda parte também está subdividida em duas seções, de acordo com as vias propostas de acesso às razões eternas em Tomás de Aquino, seja a partir de Fabro (seção 2.1), seja a partir de Lima Vaz (seção 2.2). A terceira parte, "Metafísica do conhecimento finito e a pergunta pela participação nas razões eternas", faz um breve balanço crítico, propondo uma alternativa às duas leituras, através de um enxerto especulativo-hermenêutico na "dialética da participação" de Lima Vaz (seção 3).

\section{Conhecimento e participação.}

Iremos distinguir, nesta primeira seção, dois níveis ou planos de discussão que, ao final, se entrecruzam diante das duas leituras acerca da concepção de participação nas razões eternas em Tomás de Aquino: as leituras de Cornelio Fabro e Lima Vaz (seção 2). De início tomaremos um caminho mais próximo ao texto medieval (1.1) e, em seguida, iremos propor uma interpretação que, se pode ser vista como questionável do ponto de vista histórico, não pretende se afastar da intenção do autor, e trilha o que dele permanece problemático ou impensado, do ponto de vista teórico (1.2).

\subsection{Tomás de Aquino e as razões eternas (Sth. Ia, q. 84, a. 5).}

[1] O tópico sobre as razões eternas está situado no bloco das questões 84-89, da Primeira Parte da Suma de Teologia, relativo ao conhecimento intelectual humano. A questão 84 trata sobre como a alma unida ao corpo conhece o que é corporal, que the é inferior. Esta questão está dividida em oito artigos: Se a alma conhece os corpos pelo intelecto (a. 1); Se os intelige pela sua essência ou por algumas espécies (a. 2); Se por algumas espécies, se as espécies de todos os inteligíveis lhe são naturalmente inatas (a. 3); Se lhe advêm de algumas formas imateriais separadas (a. 4); Se nossa alma vê, tudo o que intelige, nas razões eternas (a. 5); Se adquire o conhecimento inteligível a partir do sentido (a. 6); Se o intelecto pode inteligir em ato por espécies inteligíveis que tem em si, sem se voltar para as fantasias (a. 7); Se o juízo do intelecto é impedido pelo impedimento das capacidades sensitivas (a. 8). O artigo $5^{\circ}$ da questão 84 está, portanto, situado primeiramente a partir de uma discussão sobre o processo do conhecimento humano e tem a seguinte formulação no início do próprio artigo: "Se a alma intelectiva conhece as 
coisas materiais nas razões eternas" (Utrum anima intellectiva cognoscat res materiales in rationibus aeternis). É nossa intenção considerar, em especial, o papel da noção metafísica de participação que estará suposto no acesso da alma intelectiva às razões eternas.

Tomás de Aquino inicia a exposição do artigo 5º, como ocorre com cada artigo da Suma de Teologia, de acordo com a estrutura corrente de um artigo de questão disputada, embora com uma formulação mais simples: "Parece que a alma intelectiva não conhece as coisas materiais nas razões eternas". Em seguida são apresentados três argumentos ou objeções, também contrários à tese que Tomás de Aquino pretende sustentar. $\mathrm{O}$ primeiro argumento parte do seguinte ponto: "aquilo em que algo é conhecido é ele próprio mais conhecido e anteriormente". Assim, se pudermos conhecer "em que" algo é conhecido devemos supor uma anterioridade quanto à capacidade de apreensão do que se conhece. "Ora, a alma intelectiva do ente humano, no estado da vida presente, não conhece as razões eternas, pois não conhece o próprio Deus no qual as razões eternas existem". Noutras palavras, de acordo com Dionísio, não temos conhecimento do próprio Deus, mas a alma intelectiva "a ele se une como desconhecido" (Teologia Mística, c. 1). Se o próprio Deus é incognoscível, isto é, aquilo "em que" as razões eternas seriam conhecidas pela alma intelectiva, então "a alma não conhece nas razões eternas". Há, aqui, uma forte referência à argumentação da teologia negativa contra a pretensão do conhecimento intelectual humano de acesso às razões eternas. A segunda objeção recorre a uma passagem de Paulo (Rm 1,20), e a terceira objeção recorre a Agostinho. Esta terceira objeção é a mais importante para o próprio o propósito de Tomás de Aquino, já que todo o artigo $5^{\circ}$ tem como intenção fornecer uma espécie de "drible intelectual" em Agostinho, na medida em que formula uma interpretação da doutrina agostiniana da "iluminação" no sentido de torná-la compatível com a teoria do conhecimento de tipo aristotélico, que sustenta o vínculo de nosso conhecimento intelectual à experiência sensorial. No terceiro argumento, no extremo oposto do que ocorre na primeira objeção, a alma intelectiva conheceria tudo nas razões eternas, e a própria ciência se identificaria com a ciência das ideias, de acordo com o modelo platônico:

as razões eternas nada mais são que ideias. Para Agostinho, no livro das Oitenta e três questões, 'as ideias são as razões imutáveis das coisas existentes na mente divina'. Se, portanto, se diz que a alma intelectiva conhece tudo nas razões eternas, volta-se à doutrina de Platão, segundo a qual toda ciência deriva das ideias ${ }^{4}$.

A terceira objeção traz à baila um importante capítulo na história da metafísica, ao retomar, através de Agostinho, que "as ideias são razões estáveis das coisas, existentes na mente divina". Em sentido contrário (sed contra), Agostinho também é mobilizado, apoiando-se agora no livro

${ }^{4}$ STh, q. 84 , a 5, obj. 3. 
XII das Confissões: "Ora, a verdade incomutável está contida nas razões eternas. Logo, a alma intelectiva conhece toda a verdade nessas razões." ${ }^{\prime 5}$. O que está em jogo na discussão, portanto, diz respeito à fonte do conhecimento verdadeiro, isto é, a verdade imutável contida nas razões eternas. Entretanto, antes de avançarmos diretamente para a resposta de Tomás de Aquino, será preciso observar algo que terá relevância mais adiante (seção 1.2), no contexto da discussão sobre o dinamismo transcendental do espírito humano: Deus é a causa de maxime communia, mas esta não é a razão de se estabelecer a relação entre as noções transcendentais (ser, unidade, verdade e bondade) e o divino: não devemos dizer que Deus é bom à medida que é causa da bondade, mas o inverso: porque Deus é Bondade, então difunde o bem nas $\operatorname{coisas}^{6}$. Os nomes que atribuímos a Deus significam sua substância divina, mas permanecem representações deficientes, porque os nomes que lhe atribuímos representam o que nosso intelecto conhece dele, isto é, o que apreendemos a partir das criaturas. Deus contém em si todas as perfeições das criaturas. Uma criatura é semelhante a Deus enquanto dotada de alguma perfeição; ela representa a Deus não como algo da mesma espécie ou gênero, mas como princípio transcendente de cuja forma os efeitos são deficientes: os nomes que lhes são atribuídos significam a substância divina, mas, como criaturas, o fazemos de modo imperfeito. A proposição "Deus é Bom", portanto, não quer dizer "Deus é causa da Bondade", mas tem outro sentido: "o que chamamos de bondade nas criaturas preexiste em Deus". Tomás de Aquino adota o modelo platônico de predicação, mas não sua aplicação ao gênero e às espécies nas coisas naturais. Ele diferencia dois modos de predicação, que acentua não apenas a diferença entre Deus e as criaturas, mas também se refere à sua relação íntima de dependência causal: algo é bom (ser, uno ou verdadeiro) per essentiam ou per participationem. O ser (ens) é predicado essencialmente apenas de Deus, na medida em que o ser divino (esse) é subsistente e ser absoluto; nas criaturas a predicação ocorre apenas por participação, porque toda criatura não é ser (esse), mas tem ser. Deste modo, a criatura somente pode ser qualificada como "boa" por participação em Deus, que é "bondade" em si. Neste sentido toda criatura é um ente participativo (ens participative) ${ }^{7}$ e a própria ideia cristã de criação é pensada nos termos da noção de participação8.

No corpo do artigo, Tomás de Aquino apresenta um Agostinho cônscio de sua relação com a via platonica. Daí sua consideração inicial, após citar uma

\footnotetext{
${ }^{5}$ STh. q. 84, a 5, sed contra.

${ }^{6}$ Cf. STh. Ia, q. 13, a. 2. Ver aqui a concordância com De doctrina christiana (I, 32) de Agostinho: "Porque Ele é bom, nós somos.".

7 STh. Ia, q. 104, a.1c. : "omnis autem creatura est ens participative, non quod sua essentia sit ius esse.". Neste ponto Tomás de Aquino exclui qualquer interpretação panteísta da participação.

${ }^{8}$ Cf. STh. Ia, q. 44, a. 1. Tomás de Aquino procura conectar seu argumento a respeito da participação à discussão de Aristóteles (Metafísica, II) sobre o ente em relação ao maximum.
} 
passagem do livro II Da doutrina cristã de Agostinho sobre a possibilidade de harmonizar as doutrinas dos gentios e a fé cristã:

Por isso, Agostinho que fora imbuído das doutrinas dos platônicos, se encontrou algo em acordo com a fé, em seus escritos, o tomou; mas o que encontrou em oposição à nossa fé, mudou para melhor. - Ora, Platão sustentou, como foi dito acima [a. 4], que as formas das coisas subsistiam por si separadas da matéria e chamava-as de "ideias", por cuja participação, dizia ele, o nosso intelecto conhece tudo. (...) Parece, porém, que é estranho à fé que as formas das coisas subsistam por si sem a matéria, fora das coisas, como os platônicos sustentaram ao dizer que a "vida por si" ou a "sabedoria por si", são certas substância criadoras, como Dionísio diz no capítulo XI dos Nomes divinos. Por isso, Agostinho, no livro das Oitenta e três questões, sustentou, no lugar destas ideias que Platão sustentava, que as razões de todas as criaturas existem na mente divina, de acordo com as quais também, a alma humana conhece tudo. ${ }^{9}$

A ênfase da argumentação recai, em primeiro lugar, sobre o aspecto cognoscitivo da alma humana: a análise das razões eternas complementa, sob um viés epistemológico, o que foi tratado anteriormente na questão $15 \mathrm{De}$ ideis, da Suma de Teologia. Ao perguntar sobre se a alma humana conhece tudo nas razões eternas, no artigo $5^{\mathbf{o}}$ Tomás de Aquino responde de tal modo a preservar, por um lado, a autoridade de Agostinho no plano metafísico-teológico e, ao mesmo tempo, pensando-a já nos quadros epistemológicos de Aristóteles. Ora, diz Tomás de Aquino, de duas maneiras se pode conhecer uma coisa em outra: (1) conhecendo-a em um objeto conhecido, como se vê "em um espelho coisas cujas imagens estão nele refletidas"; (2) conhecendo-a como em um princípio de conhecimento, como se vê "no sol o que vemos por sua luz". Os exemplos que Tomás de Aquino escolhe para sustentar seu argumento, é claro, não são casuais, pois estão inscritos na tradição platônica: in speculo, in sole. No primeiro caso, não podemos conhecer as coisas materiais nas razões eternas, porque a alma, no estado da vida presente, não vê a Deus. Esta é a maneira de conhecer apenas daqueles que alcançaram a beatitude, que veem a Deus e tudo nele. No segundo caso, porém, a alma humana conhece tudo nas razões eternas, no sentido de que é pela marca divina em nós que tudo nos é mostrado. Mas, para Tomás de Aquino, será necessário interpretar adequadamente o que propõe Agostinho:

No entanto, como, além da luz intelectual em nós, são exigidas as espécies inteligíveis recebidas das coisas, para se ter ciência das coisas materiais, não temos notícia das coisas materiais apenas pela participação das razões eternas, como os platônicos sustentaram que apenas a participação das ideias basta para ter ciência. ${ }^{10}$

${ }^{9}$ STh Ia, 84 , a 5 c.

${ }^{10}$ STh Ia, q. 84, a 5 c. Esta concepção de participação aqui implicada supõe o que já foi exposto anteriormente, acerca da relação de eficiência e finalidade entre criatura e Criador. Cf. STh. Ia, q. 44 , a. 1. 
Temos, portanto, alguma noção das razões eternas, como algo já inscrito em nós. Tomás de Aquino cita o Salmo 4, 6-7, que se refere à felicidade, ilustrando com isso o fato de que o selo da luz divina está marcado em nós. O desejo da felicidade, assim como o desejo de ver a Deus, está inscrito previamente em nós ${ }^{11}$. De acordo com a perspectiva agostiniana, no intelecto humano há uma participação da luz divina em nós. Mas isto, acentua Tomás de Aquino, ainda não é propriamente conhecer o ser de Deus: ter por participação a luz intelectual não seria suficiente para o conhecimento das coisas ${ }^{12}$. Noutras palavras, será necessário repensar a intelligentia spiritualis agostiniana, o campo onde, segundo Lima Vaz, "a intentio Augustini foi mais profundamente captada e assimilada por Tomás de Aquino"13. Diante de Agostinho será preciso afirmar que, para o completo concurso do conhecimento humano, deveríamos recorrer, necessariamente, às species intelligibiles recebidas das coisas materiais ${ }^{14}$. Com isso o caminho está aberto para o passo seguinte, desenvolvido no artigo $6^{\circ}$, em confronto mais direto com Aristóteles: "Se o conhecimento intelectivo é recebido das coisas sensíveis" (Utrum intellectiva cognitio accipiatur a rebus sensibilibus). $\mathrm{O}$ caráter matizado e ao mesmo tempo bastante compacto do artigo $6^{\underline{0}}$ será um encadeamento do artigo 5o, que nos mostra porque Tomás de Aquino não precisa escolher entre Agostinho e Aristóteles, já que ambos não estão falando sobre a mesma coisa: Aristóteles está falando do processo do conhecimento intelectual humano enquanto Agostinho está falando da fonte transcendente de Deus, o locus das razões eternas. ${ }^{15}$.

[2] Após a apresentação do artigo $5^{\underline{0}}$, resta ainda acentuar um ponto importante da nossa análise, que diz respeito a uma controvérsia entre medievalistas ${ }^{16}$ e está conectada a nossa crítica à interpretação de Corne-

\footnotetext{
${ }^{11}$ Para uma comparação sobre o nosso conhecimento prévio (embora confuso) acerca de Deus, e o nosso desejo de felicidade, ver STh Ia q. 2, a 1 ad 1 . O que está em jogo, aqui, não é a negação de algum conhecimento, mas destacar a diferença entre conhecer e reconhecer (enquanto tal) a existência de Deus.

${ }^{12} \mathrm{O}$ conhecimento das coisas pela alma intelectiva supõe, portanto, uma dupla fonte: (a) a luz intelectual que se exerce no trabalho de abstração do intelecto agente; (b) A outra fonte são as species intelligibiles. Ver também, sobre a relação entre as razões eternas e o intelecto agente no processo cognoscitivo de participação na luz incriada, BOLAND, Vivian. Ideas in God according to Saint Thomas Aquinas: sources and synthesis. Leiden/New York/Köln: Brill, 1996, p. 281.

${ }^{13}$ AF I, 254.

${ }^{14}$ Uma mesma concepção de fundo, em conexão com Agostinho, no artigo seguinte, esclarece em que sentido deveríamos interpretar a frase "non est expectanda sinceritas veritatis a corporis sensibus" (livro 83, q. 46). STh. Ia, q. 84, a 6 ad 1: "quod per verba illa Augustini datur intelligi quod veritas non sit totaliter a sensibus expectanda. Requiritur enim lumen intellectus agentis, per quod immutabiliter veritatem in rebus mutabilibus cognoscamus, et discernamus ipsas res a similitudinibus rerum."

${ }^{15}$ Cf. NASCIMENTO, Carlos, A. Ribeiro do: “Tomás de Aquino entre Agostinho e Aristóteles". In: P. M. PALACIOS (Org.), Tempo e Razão: 1.600 anos das Confissões de Agostinho. São Paulo: Ed. Loyola, 2002, p. 63-73.

${ }^{16}$ Cf. VELDE, Rudi te. Participation and Substantialy in Thomas Aquinas, Leiden, Brill, 1995, p. 87-206.
} 
lio Fabro acerca de Tomás de Aquino, como veremos adiante (seção 2.1), a saber: a perspectiva sobre a inteligibilidade da criação, entendida em termos de participação, isto é, o modo como esta pode ser desvelada pela mente humana ${ }^{17}$. Tomás de Aquino segue Agostinho ao conceber que as ideias ou exemplares são formas-princípios das criaturas na mente divina. Deus é a causa exemplar primeira de tudo ${ }^{18}$. A sabedoria divina tem em sua mente a ordem do universo e dispõe tudo de modo diferenciado. Assim, na sabedoria divina estão todas as razões eternas (ideias), ou seja, as formas exemplares existentes na mente divina. Há aqui uma retomada da problemática clássica da relação entre o Uno e o Múltiplo no quadro referencial da metafísica da criação ${ }^{19}$ : os exemplares são múltiplos de acordo com a diversidade das criaturas, mas não se diferenciam da essência divina. A similitude com Deus pode ser participada de modos diversos por tudo que é criado. Mas será preciso compreender a similitude divina nos seres criados não como a atualização de possíveis essências das coisas na mente divina. A essência divina é a ideia de todas as coisas, não enquanto identidade consigo mesma (ut essentia), mas enquanto as coisas são inteligidas (ut intellecta). Assim, a similitude de cada criatura pode ser inteligida por Deus na medida em que as coisas assimilam diversamente e em distintos graus a infinita perfeição de sua essência: Deus as conhece na distinção entre essência e ser (esse), isto é, per participationem. Cada ente (ens) se distingue e participa de Deus, que é Ipsum Esse. Essa diferença é preconcebida em Deus na ideia de cada criatura. Deus é causa de todas as diferenças múltiplas dos entes ${ }^{20}$. O ente enquanto ente (ens) é um "outro" em relação ao ser (esse), na medida em que é uma similitude (per participationem) da essência de Deus: as criaturas não participam da essência divina enquanto tal, mas em sua similitude, e precisamente enquanto similitude é distinguida da essência divina em si mesma (per essentiam). A participação é um modo de conceber a "diferença na unidade". Há apenas um ato de criação: Deus não atualiza as múltiplas possibilidades (possibilia) das criaturas previamente em sua mente. $\mathrm{O}$ efeito do ato de criação procede da causa em virtude de uma ativa autodistinção a partir da própria causa: Deus produz a "alteridade" das criaturas em relação a si, precisamente enquanto similitude divina nas criaturas. Não há uma dupla criação ou "dupla participação": uma anterior (essência) na mente de Deus, e outra na pro-

${ }^{17}$ Cf. STh. Ia, q. 44 a.2 c; De pot. q. 3, a. 5 c.

${ }^{18}$ Cf. STh. Ia, q. 44 a. 3.

${ }^{19}$ Cf. VELDE, Rudi te. Aquinas on God: The 'Divine Science' of the Summa Theologiae. (Ashgate Studies in the History of Philosophical Theology). England/USA, 2006, p. 123-125; p. 150-155. Ver também, do mesmo autor, Participation and Substantiality in Thomas Aquinas, op. cit., p. 134-159. Do ponto de vista metafísico a doutrina da criação em Tomás de Aquino ocorre à luz da noção platônica de participação e da noção aristotélica de substância, mas Tomás de Aquino opera uma transformação conceitual na recepção dessas noções.

${ }^{20}$ De pot. q. 3, a. 16 ad 4: “(...) illud quod est causa entis in quantum est ens, esse causam omnium differentiarum entis, et per consequens totius multitudinis entium." 
dução da existência atual (esse). Para Tomás de Aquino exemplaridade e eficiência são dois aspectos de uma única causalidade divina ${ }^{21}$.

\subsection{O dinamismo transcendental do espírito e a pressuposição do Absoluto.}

Neste segundo momento avançamos para um plano de discussão que pretende partir do texto medieval (STh. Ia q. 84 a.5), historicamente situado, mas que dele retira um impulso para levantar questões teóricas mais amplas. Há dois aspectos que iremos destacar aqui, na discussão sobre como relacionar a "ciência das coisas materiais" e a "participação" nas razões eternas. São eles: [1] a defesa de uma pré-compreensão do Absoluto (no sentido de algum conhecimento positivo de Deus) e [2] a dupla transcendência do ser e o dinamismo transcendental do espirito. Os dois aspectos devem ser vistos como conectados à tentativa de conceber o papel da participação nas razões eternas. Na segunda seção deste artigo serão apresentadas duas estratégias contemporâneas de pensar a "participação nas razões eternas segundo Tomás de Aquino", vinculadas pela constatação comum sobre a importância da noção metafísica de participação e sobre o modo divergente de pensar nosso acesso às razões eternas. Os dois aspectos, levantados a seguir, têm como intenção um esclarecimento preliminar sobre o que estará em jogo posteriormente (seção 3), no breve confronto com as duas leituras.

[1] De início é preciso considerar que Tomás de Aquino encontra em Aristóteles, do ponto de vista do processo do conhecimento, uma condição restritiva de nosso acesso às razões eternas. Com efeito, ele retoma as indicações de Dionísio, propostas no primeiro argumento: o conhecimento humano do ente se refere ao ente material; o ente imaterial (sobretudo Deus) é muito mais apontado do que compreendido: "ei sicut ignoto conjungitur". Não conhecemos nem mesmo as diferenças essenciais das espécies

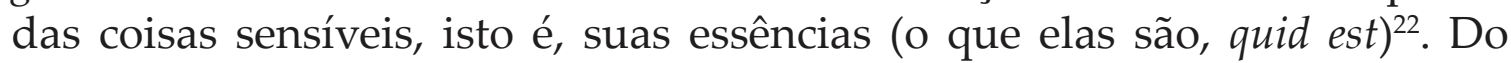
ponto de vista histórico-textual não há expressamente uma intuição do ente imaterial, mas apenas um penoso esforço para pensar a causa primeira a partir dos seus efeitos. Daí a formulação posta atualmente em circulação e acentuada por alguns intérpretes, sobre o papel do juízo negativo em nosso conhecimento de Deus: nesta vida temos somente um conhecimento não-quididativo de Deus ${ }^{23}$. Entretanto, uma perspectiva radicalmente apofá-

\footnotetext{
${ }^{21}$ A fonte da participação causal aqui expressa provém do modo como Tomás de Aquino repensa Dionísio, isto é, como a causa divina pode ser conhecida através da concepção de similitudo. Cf. In de div. nom. c. 5, lect. 2, n. 662.

${ }^{22}$ Cf. STh. Ia, q. 88.

${ }^{23}$ Sobre o conhecimento não-quididativo de Deus e o papel do juízo negativo em Tomás de Aquino, ver especialmente WIPPEL, John. "Quidditative Knowledge of God and Analogical Knowledge". In: The Metaphysical Thought of Thomas Aquinas, Washington D.C.: The Catholic
} 
tica de Deus, sem alguma noção positiva do divino, não impossibilitaria o acesso às razões eternas? Como compatibilizar essa visão com a afirmação de Tomás de Aquino segundo a qual o objeto próprio do intelecto humano, como ente racional, é a quididade dos entes materiais? Para evitar uma contradição flagrante nos termos de Tomás de Aquino, propomos assumir que a expressão "quididade dos entes materiais" não signifique a essência dos mesmos, mas todo conhecimento que permita identificar o que eles são e diferenciá-los de outras coisas, ainda que seja meramente por diferenças acidentais. Assim, é preciso enfatizar que, se ainda quisermos falar em "conhecimento negativo" a partir de Tomás de Aquino, isto não deveria ser concebido em termos agnósticos ou nos mesmos termos da teologia negativa de Dionísio (apofatismo absoluto), pois a compreensão da negação está fundada em alguma afirmação ${ }^{24}$. Na verdade, o juízo negativo pressupõe o juízo positivo em dois sentidos: o positivo que é negado e o positivo que fundamenta a negação. O positivo que é negado corresponde ao objeto formal do próprio intelecto humano enquanto racional, isto é, diz respeito ao conhecimento intelectual explícito do sensível (quidditas rerum materialium). Por outro lado, o positivo que fundamenta a negação seria o conhecimento implícito do ente enquanto ente, o ente em seu todo, que corresponderia ao objeto formal do intelecto humano enquanto intelecto. Assim, podemos falar de uma explicitação da noção transcendente de ente (ratio entis) não no sentido de uma abstração generalizante, mas por uma extensão explícita desta noção a tudo o que é. De fato, o juízo negativo (separatio) cumpre, em dois níveis, uma função decisiva nesse processo ao nos permitir apreender o significado metafísico da noção de ser (isto é, não como mera atualidade factual ou enquanto entidade determinada): a afirmação do ser supõe a remoção de qualquer materialidade e, em segundo lugar, qualquer limitação ou finitude. Neste ponto podemos considerar se realmente não estaria suposto - para além do que o próprio Tomás de Aquino literalmente expressa - uma forma de intuição intelectual abstrativa, implicada na distinção presente no processo intelectivo humano entre ratio e intellectus: enquanto ratio significa a capacidade do pensamento conceptualmente discursivo (mediação da razão), intellectus diz respeito à capacidade mais elevada de percepção espiritual imediata (imediatez do intelecto). $\mathrm{O}$ inteligir (intelligere) tem o caráter de um ver ou intuir (noein, nous) e exprime o significado entendido em um conceito (concipere,

University of America Press, 2000, p. 501-575; "Quidditative Knowledge of God". In: Metaphysical Themes in Thomas Aquinas, op. cit., p. 220-222.

${ }^{24}$ Cf. De pot. q. 7 a. 5. Daí a possibilidade de pensar o alcance do juízo negativo de separação (separatio) não apenas no sentido lógico-conceitual, mas também no sentido de uma afirmação ontológica do ser (esse), de acordo com a interpretação de J. Maréchal, que nos parece mais próxima dos textos de Tomás de Aquino do que, por exemplo, a de Joseph de Tonquedéc. Cf. EF III: FC, 320-326. Sobre a compreensão mais precisa de alguns enunciados puramente negativos presentes no texto de Tomás de Aquino, ver também PUNTEL, Lorenz B. Ser e Deus: Um enfoque sistemático em confronto com M. Heidegger, É. Lévinas e J. -L. Marion. São Leopoldo, RS: Ed. UNISINOS, 2011, p. 240-242. 
species, verbum mentis). Esses dois elementos não se opõem em Tomás de Aquino ${ }^{25}$; relacionam-se mutuamente, uma vez que, sob uma perspectiva hermenêutica, a imediatez do intelecto, através da mediação da razão, deve nos conduzir à expressividade conceitualmente articulada e diferenciada. A compreensão de sentido supõe necessariamente uma exposição interpretativa do que é compreendido. O intellectus apreende imediatamente a unidade e a totalidade, enquanto a ratio a desdobra analiticamente. Assim, os efeitos que nos levam a conhecer positivamente (compreender/intelligere) os atributos de Deus por participação não são propriamente dos entes sensíveis, mas da alma humana como ente espiritual, como presente a si mesma em seus atos e em sua experiência. Não é o caso de falarmos aqui de uma intuição da essência da alma, mas sim de um conhecimento de seu modo de ser em exercício, enquanto alma intelectiva, já que o significado da experiência da alma só pode ser expresso por analogia, partindo das realidades sensíveis. A noção de ser (ratio entis) como ser subsistente, em Tomás de Aquino, confere aos entes finitos a sua existência, enquanto eles participam de seu ser. A verdade do ser (veritas rei), pela qual o ente é inteligível, corresponde à sua ideia no intelecto divino; é o ser divino que confere inteligibilidade e sentido ao ente criado $^{26}$. Assim, o ser do ente consiste na sua presença efetiva na realidade (in rerum natura), enquanto criado por Deus - o que permitiria aproximar esta experiência daquilo que Heidegger chama de "existencialidade" (Vorhandenheit).

[2] Em sentido mais amplo do que está expresso literalmente em Tomás de Aquino, devemos aqui acentuar o seguinte: o fundamento do juízo negativo consistiria no dinamismo transcendental do espírito humano, que nos conduz, através do segundo passo da separatio, a ultrapassar (per excessum) ${ }^{27}$ os limites de toda essência, de modo a nos conduzir ao conhecimento de Deus para além do ente enquanto ente, a saber: o conhecimento de Deus como princípio absolutamente incompreensível de todo ente. Esta segunda operação é própria do conhecimento metafísico e nos aponta para o sentido de ser como ato de todos os atos e perfeição de todas as perfeições ${ }^{28}$. Deus é a plenitude absoluta de ser como Ipsum Esse Subsistens e as criaturas são participações do ser em diversos modos e graus. Tomás de Aquino reconhece, com Agostinho, que o ser humano está naturalmente voltado a Deus, pela vontade e pelo conhecimento. Deus está presente no espírito humano: ao conhecer a si mesmo, faz de certo modo uma implícita experiência de Deus presente em seu espírito. Não se trata, é claro, de uma intuição da essência de Deus, mas um apontar para Ele na medida em que o ser humano tem uma experiência da ilimitação intensiva de seu espírito, na abertura ao ente no seu todo. O excessus é, neste sentido fundamental, a experiência desse dinamismo ilimitado de explicitação,

\footnotetext{
${ }^{25}$ Cf. STh. Ia. q. 79 , a. 8.

${ }^{26}$ Cf. De Veritate, q. 1, a. 4 ad 5.

${ }^{27}$ Cf. STh. Ia, q. 6, a. 2 ad 3.

${ }^{28}$ Cf. De Pot., q. 7, a. 2 ad 9.
} 
no espírito humano, da afirmação implícita de Deus. Há, portanto, uma dupla transcendência do intelecto humano no sentido do dinamismo de autosuperação que caracteriza nosso espírito, quer em relação ao ente, quer em relação ao próprio intelecto e seu ato: a primeira transcendência seria extensiva, isto é, diz respeito ao seu objeto formal, universalizante (a saber: o ens commune); a segunda seria intensiva (per excessum), na medida em que alcança de algum modo o princípio ou causa do ente enquanto ente $^{29}$. É neste sentido que seria permitido dizer que Deus pode ser conhecido de certo modo a priori, algo que não está suficientemente desenvolvido em Tomás de Aquino, mas que, assim interpretamos, está de acordo com sua intenção última e corresponde a um aspecto fundamental de seu pensamento $^{30}$. Esta visão da transcendência foi adequadamente captada por Karl Rahner em sua releitura transcendental-metafísica da epistemologia de Tomás de Aquino, ao traduzir a noção de excessus por antecipação/pré-compreensão (Vorgriff), embora esta formulação não corresponda ao uso estritamente histórico de ultrapassamento (excessus) que dele faz S. Tomás (uso este que provém de Dionísio) ${ }^{31}$. Em suma: há implicitamente algum conhecimento positivo de Deus em Tomás de Aquino, presente na finitude do intelecto humano, o que permitiria acesso da alma intelectiva às razões eternas; mas esta interpretação sugere mais a intenção do autor do que aquilo que, explicitamente, encontra-se em seus escritos, exigindo assim uma elaboração mais sistemática em nosso atual horizonte de compreensão. Estas considerações prévias estão de acordo com a noção de inteligência espiritual, tal como foi exposta por Lima Vaz, e devem nortear a discussão posterior: a especificidade do ser humano em sua relação com o mundo se mostra, em última instância, na capacidade da inteligência de elevar o que se encontra na esfera sensível à ordem universal do sentido, seguindo a rota da segunda navegação platônica ${ }^{32}$.

\section{Duas leituras sobre o papel da noção de participação nas razões eternas.}

Cornelio Fabro e Lima Vaz têm em comum a tentativa de pensar a noção metafísica de participação em Tomás de Aquino como parte constitutiva

${ }^{29}$ Cf. RAHNER, Karl. Geist in Welt: Zur Metaphysik der endlichen Erkenntnis bei Thomas von Aquin. München: Verlag, 3. Auflage, 1964, p. 388.

${ }^{30}$ Cf. De Veritate q. 1, a. 1.

${ }^{31}$ Uma crítica à posição de K. Rahner e sua interpretação da noção de excessus/Vorgriff em Tomás de Aquino (na linha do assim chamado "tomismo transcendental"), encontra-se em FABRO, Cornelio. SA; Ver também HOERES, Walter. "Critique of the Transcendental Metaphysics of Knowing: Phenomenology and Neo-scholastic Transcendental Philosophy. Aletheia 2 (1977): 353: 69; POSSENTI, Vittorio. Nihilism and Metaphysics: The third Voyage, op. cit., p. 325-331.

${ }^{32}$ Cf. AF I, 239-289. 
da concepção de esse como actus essendi, embora apresentem diferentes estratégias de interpretação sobre o processo intelectual humano de acesso às razões eternas de Deus. No que se refere a uma comparação crítica acerca das duas estratégias, há razões históricas (o papel central do juízo negativo para a afirmação do ser) e teóricas (a pré-compreensão do Absoluto) para optarmos pela interpretação de Lima Vaz (apesar de sua conceitualidade "lógico-dialética") no âmbito desta discussão, ao reconsiderarmos a análise da dialética da participação em sua conexão com o juízo na afirmação do ser. Entretanto, como em seguida será indicado no breve balanço dessa comparação (seção 3), nossas opções teóricas voltam-se mais precisamente para a explicitação crítica das características essenciais das respectivas interpretações de Tomás de Aquino sob uma perspectiva especulativo-hermenêutica ${ }^{33}$.

\subsection{Participação e razões eternas de acordo com Cornelio Fabro: via platonica.}

[1] A partir de meados da década de 1930 ocorreu uma "redescoberta" da chamada "originalidade do esse (ser) em Tomás de Aquino", isto é, a identificação do esse com o actus essendi (ato de ser). Este foi um passo sumamente importante na diferenciação entre os entes e o Ser, ao se reconhecer claramente que Tomás de Aquino concebia Deus em primeiro lugar como Esse per se Subsistens (e não como primum ou summum ens). Entretanto, neste primeiro momento a "redescoberta" não foi além de interpretações basicamente históricas de seus textos, não tendo ainda como horizonte de compreensão os problemas da cultura pós-medieval e as coordenadas teóricas do pensamento moderno. Com relação à noção de participação não foi diferente. De fato, uma forma inadequada de pensar a estrutura analógica do Verbum de Deus (a "dependência" primeira e radical da criatura ao Criador) a partir da noção de participação pode

\footnotetext{
${ }^{33}$ Esta perspectiva se pretende, pois, compatível com uma teoria do Absoluto: ela supera, por um lado, o antropocentrismo da filosofia da subjetividade na linha de Kant e Fichte, e, por outro lado, reafirma de modo crítico a noção de verdade em sentido objetivo (com status objetal), em especial ao distinguir (contra Heidegger e Gadamer) entre "retidão" e "manifestação", verdade como acontecer histórico e verdade objetiva (ontológica). Ainda assim, apesar de avanços conceituais mais precisos na relação entre "compreensão" e "verdade", a sistematização da metafísica na linha aberta por Emerich Coreth carece de um diálogo mais amplo com a filosofia analítica contemporânea, no que se refere não apenas à necessidade de assimilar um conceito de verdade menos ambíguo, mas também no sentido de uma revisão crítica da ontologia da substância, que subjaz à estrutura da metafísica clássica de Tomás de Aquino. Entretanto, como podemos aqui apenas indicar, Coreth está correto em ressaltar (na esteira de Karl Rahner e J. Lotz) uma possível complementação recíproca das abordagens sobre a questão do ser em Tomás de Aquino e Heidegger. É nossa intenção, no posterior recorte da dialética da participação em Lima Vaz (seção 3.2), acentuar a pertinência de um enxerto especulativo-hermenêutico na discussão sobre a vida do espírito.
} 
ser expressa justamente na obra de Cornelio Fabro, um autor cujo mérito consiste, sobretudo, em enfatizar o substrato platônico e neoplatônico como constitutivo do primado do esse-actus essendi na obra de Tomás de Aquino, contra a interpretação "aristotélico-tomista" parcial e dominante na neoescolástica de seu tempo.

[2] Para Cornelio Fabro, Tomás de Aquino teria formulado uma doutrina própria, cuja noção metafísica central seria a de participação, capaz de explicar o caráter causal de nossa relação com Deus em termos epistêmico e metafísico ${ }^{34}$. Em termos epistêmicos, porque constatamos que nosso acesso a Deus somente pode ocorrer através dos entes finitos; em termos metafísicos, porque o próprio ato de conhecer supõe uma realidade que provém da causalidade de um ser supremo. De acordo com Fabro a síntese doutrinal de Tomás de Aquino se revela absolutamente original quando observamos suas fontes: aceita o núcleo metafísico da transcendência platônica (noção de criação, composição de esse e essentia, doutrina da analogia) em conexão com o ato da imanência aristotélica (a unidade da forma substancial, a alma intelectiva como forma substancial do corpo, a doutrina da abstração) ${ }^{35}$. A reinterpretação da epistemologia de Agostinho em termos aristotélicos, proposta por Tomás de Aquino, relaciona-se com a adoção da via platonica do Bispo de Hipona e sua noção de participação nas razões eternas de Deus $^{36}$. No que se refere ao bloco das questões relativas ao conhecimento intelectual humano na Primeira Parte da Suma de Teologia Cornelio Fabro trata, na obra A Noção Metafísica de Participação segundo S. Tomás de Aquino, apenas das questões $84^{\underline{a}}$ e $85^{\text {a }}$. Da questão $84^{\mathrm{a}}$ são tratados apenas os artigos $4^{\circ}$ (ad 1) e 5․ O artigo $4^{\circ}$ é citado uma única vez e o artigo $5^{\circ}$ é citado duas vezes. A primeira referência ao artigo 5o, em particular, é feita no contexto da exposição sobre as fontes secundárias, na linha da tradição greco-cristã de Tomás de Aquino. Como mediação neoplatônica para a noção de participação, é claro, destaca-se Agostinho ${ }^{37}$. Neste contexto seria importante confrontar uma conhecida asserção de É. Gilson, a saber: que há um acordo em considerar a substituição da síntese doutrinal

\footnotetext{
${ }^{34}$ Cf. NMP; PC; IH. Sobre a relevância de Cornelio Fabro e sua noção de participação como fundamentada no esse, enquanto ato supremo intensivo (actus essendi), ver BOLAND, Vivian. Ideas in God according to Saint Thomas Aquinas: sources and synthesis, op. it. p. 259-260.

${ }^{35}$ Fabro acentua que a originalidade da dialética do esse em Tomás de Aquino foi mais plenamente desenvolvida somente em seus escritos tardios, quando ocorre um conhecimento mais direto de alguns escritos neoplatônicos, como aqueles de Proclo e Porfírio. Uma importante referência neste contexto seria, por exemplo, De substantiis separatis (1272-73). Cf. IH, 468-469. Este texto de Fabro (IH) sintetiza elementos fundamentais de seus dois livros sobre a noção de participação em Tomás de Aquino.

${ }^{36}$ O que Agostinho entende por participação, segundo Fabro, segue a linha do neoplatonismo plotiniano e consiste na catarse da alma em sua relação com as razões eternas, com referência ao texto de Agostinho "De Ideis". As citações do texto, utilizadas por Fabro, são extraídas da seguinte edição: D. AUGUSTINI HIPP. 83 Quaestiones, q. 46 De Ideis, P. L., t. 40, col. 29 n. 1. ${ }^{37}$ Cf. R. J. HENLE, Saint Thomas and Platonism: A study of the Plato and Platonic texts in the writings of Saint Thomas, Den Haag: Nijhoff, 1956.
} 
de Agostinho por aquela de Tomás de Aquino como o acontecimento filosófico mais importante do séc. XIII, tendo como eixo central a teoria do conhecimento $^{38}$. Dada a importância deste tópico, poder-se-ia esperar de Fabro um tratamento mais amplo sobre o bloco das questões 84-89. Mas a discussão sobre a teoria do conhecimento de Tomás de Aquino não é realizada no decorrer do tratamento dessas questões. Por isso mesmo Fabro quase nem examina o problema de nosso conhecimento de Deus no todo das questões 84-89. Em consequência, a análise do artigo $5^{\mathbf{0}}$ da questão $84^{a}$ é situada antes no âmbito mais geral da problemática sobre a noção de participação, comum a Agostinho e a Tomás de Aquino. A relação de dependência entre criatura e Criador é expressa por Agostinho com o termo "participare" e isto significa que tudo o que é criado, isto é, toda verdade, bondade, beleza etc., nas criaturas, não é senão uma participação na luz primeira, o Verbo divino ${ }^{39}$. Para Agostinho, assim como para Tomás de Aquino, observa-se na alma a existência de um "lumen intelligibile" que provém de Deus - mas é preciso dizer que o modo como se compreende o papel dessa luz divina em nós se diferencia em cada um dos seres. Fabro certamente reconhece a legitimidade da perspectiva "transcendental" de Agostinho, especialmente no que se refere à "metafísica da Ideia" que marca a filosofia de matiz neoplatônico do Bispo de Hipona. Ora, para C. Fabro, todo o artigo $5^{-}$da questão $84^{a}$ é uma tomada de posição diante da doutrina expressa pelo texto da questão 46a , De ideis de Sto. Agostinho ${ }^{40}$. Na definição agostiniana, as Ideias são exemplares eternos das coisas, contidos na mente de Deus ${ }^{41}$. Com efeito, na mente divina estão contidas todas as razões ou ideias da realidade criada ou potencialmente existente. Ao contrário da doutrina platônica das Formas ou Ideias, os princípios de inteligibilidade das coisas não estão presentes em algum âmbito da realidade à parte. Não há algo divino independente do ser de Deus ${ }^{42}$. Do

\footnotetext{
${ }^{38}$ Cf. É. GILSON, "Pourquoi S. Thomas a critiqué Saint Augustin", Archives d'Histoire Doctrinale et Littéraire du Moyen Âge 1 (1926) 5-127. Há tradução para o português: Por que São Tomás criticou Santo Agostinho. São Paulo: Ed. Paulus, 2010.

${ }^{39}$ Cf. NMP, 80.

${ }^{40} \mathrm{NPM}, 80$, n. 1: “Tutto l'art. non è che una presa di posizione di fronte alla dottrina della q. 46". As citações do texto de Agostinho, utilizadas por Fabro, são extraídas da seguinte edição: D. AUGUSTINI HIPP. 83 Quaestiones, q. 46 De Ideis, P. L., t. 40, col. 29 n. 1.

${ }^{41}$ V. BOLAND, Ideas in God according to Saint Thomas Aquinas, op. cit., p. 40.

${ }^{42} \mathrm{O}$ recurso a Deus supõe aqui que o "esse" deve abranger tudo. O ente criado é uma composição de "esse" e "essentia", e em toda criatura uma coisa é a criatura que tem o esse e outra coisa é o esse mesmo. Esse e essentia têm uma relação de alteridade recíproca: há, na relação, um "outro metafísico" (de acordo com a expressão de L. B. Puntel). Mas se nada é exterior ao "esse", como explicar essa diferença? O esse também abrange a "essentia"? Entretanto, como pode abranger a "essentia" se o ato de ser (actus essendi) for entendido como coprincípio da essentia? Neste caso, o que significa "essentia"? Seria permitido conceber a "essentia" como algo positivo, de acordo com o esquema subiectum-essentia-esse? Seria necessário pensar uma unidade originária à qual nada é exterior, mas de onde brota a diferença? Noutras palavras: como conceber a identidade da diferença? Sobre a interpretação da aporia inscrita na noção de participação como diferença real ou composição real de "esse" e "essentia", e o caráter
} 
contrário, seria supor que a atividade de Deus dependeria de algo exterior a Ele. Mas não há algo que subsista fora de sua ordem, de sua atividade criadora. As Ideias na mente divina garantem o governo do mundo e a estrutura ontológica dos entes. É neste sentido que, para Agostinho, vê-se nestas reflexões o próprio fundamento de toda verdadeira religião ${ }^{43}$. A descoberta das Ideias em Deus é feita em contraste com a doutrina platônica, a partir das dificuldades que Agostinho encontra na formulação desta concepção. No que se refere ao processo de conhecimento humano, Agostinho se baseia em sua concepção de iluminação divina, em confronto com a doutrina platônica da reminiscência ${ }^{44}$. Mas é importante observar que o caminho percorrido por Agostinho até chegar a essa descoberta é característico de seu pensamento, imerso na tradição platônica: a análise da interioridade revela, na mente humana, razões eternas e imutáveis, que não podem ter sido produzidas pelo próprio homem, pois o que é inferior não pode causar o que é superior. Para Agostinho, portanto, há uma conaturalidade entre as verdades eternas e a mente humana, embora nem todo ser humano alcance a razão última das coisas. O homem pode ter acesso às ideias com o olho interior da mente, mas esta deve estar purificada para se unir a Deus na caridade. Somente assim a alma alcança na contemplação a sua beatitude ${ }^{45}$. A purificação da mente, através da caridade, possibilita ao homem alcançar a visão intelectual acerca do ser divino. Com isso, a mente se dispõe a ser iluminada por Deus: a estrutura cognitiva humana recebe a iluminação das notiones aeternae, o que permite o acesso à verdade ou razões eternas das coisas, presentes no ser divino.

[3] A ausência de uma discussão mais ampla sobre a estrutura do juízo conectada à noção de participação compromete a inteligibilidade e a coerência, por parte de Fabro, na articulação proposta por Tomás de Aquino em dobrar a intentio Augustini na direção da noética aristotélica. Será preciso considerar o fato de que para Tomás de Aquino o juízo negativo cumpre um papel fundamental para a noção de excessus como transcendência. Ora,

\footnotetext{
"irrefletido e exterior" de Fabro, que, segundo Puntel, já poderíamos encontrar em Tomás de Aquino, ver especialmente PUNTEL, Lorenz. Em busca do objeto e do estatuto teórico da filosofia: Estudos críticos na perspectiva histórico-filosófica. São Leoopoldo, RS: Ed. UNISINOS, 2010, p. 57-58. Não é nossa intenção, é claro, desenvolver aqui o problema levantado por Puntel, e os limites deste nosso ensaio apontam para outra direção. No modo como compreendemos a questão, porém, será preciso considerar antes o equívoco de Fabro em conceber uma dupla criação (essentia e esse) a partir da causalidade divina (nos termos da distinção entre participação predicamental e participação transcendental), o que não permitiria expressar devidamente a unidade e a coerência interna do conceito de criação como participação em Tomás de Aquino. Um breve posicionamento crítico sobre a "dupla criação" encontra-se supra (seção 1.1, [2]). Sobre o problema da composição, do "outro metafísico" e sua conexão com o problema das ideias eternas, ver especialmente VELDE, Rudi te. Participation and Substantialy in Thomas Aquinas, op. cit., p. 87-91; p. 113-116.

${ }^{43}$ Cf. NMP, 81.

${ }^{44}$ V. BOLAND, Ideas in God according to Saint Thomas Aquinas, op. cit., p. 44.

${ }^{45}$ Cf. NMP, 82.
} 
isto ocorre somente porque Tomás de Aquino formula uma determinada concepção de metafísica. Além disto, a própria determinação do subiectum da metafísica está intrinsecamente relacionada àquilo que ele entende por separatio. Em sua interpretação de Tomás de Aquino, Cornelio Fabro não reconhece a importância do juízo negativo no processo de apreensão do ente. Um tópico pouco explorado por Fabro é precisamente a análise particular acerca do subiectum da metafísica em Sto. Tomás. É certo que Fabro não desconhece o locus de diferenciação entre a primeira operação e a segunda operação (separatio), tal como se encontra, por exemplo, no Comentário ao Tratado da Trindade de Boécio, q. 5, a 3. Mas, segundo Fabro, o ser do juízo é puramente formal, sem realidade própria, vinculado ainda ao "essencialismo" da metafísica aristotélica. O que é apreendido na segunda operação não corresponderia ao esse ut actus, que expressaria a originalidade de Tomás de Aquino ${ }^{46}$. É necessário observar, portanto, que Cornelio Fabro critica o recurso ao juízo negativo para a compreensão adequada da teoria do conhecimento de Tomás de Aquino ${ }^{47}$. Não estamos de acordo com este aspecto da interpretação de Fabro, uma vez que o juízo negativo cumpre um papel decisivo no conhecimento do esse como actus essenditi ${ }^{\text {. }}$

\subsection{Ser e participação nas razões eternas de acordo com Lima Vaz: via descensus, via ascensus}

[1] Uma ampliação de inteligibilidade da noção de participação. Em primeiro lugar, é preciso dizer que a presença de Fabro na obra de Lima Vaz não pode ser desprezada, precisamente pela importância que a noção de participação (e da noção correlata de analogia) ocupa no todo do sistema filosófico de Lima Vaz. No capítulo 12 de Escritos de Filosofia VII: Raízes da Modernidade, há uma constante referência a textos de Fabro, no que se refere à noção de participação ${ }^{49}$. De nossa parte consideramos que o ponto mais importante, neste contexto, diz respeito à própria estrutura analógica da participação, que foi acentuada por Fabro e subscrita por Lima Vaz, pondo em destaque a diferença entre modus significandi e res (ou ratio)

\footnotetext{
${ }^{46}$ PC 59, n. 1: “(...) ma questo dimostra ancora una volta che l'esse, qual è presente nel giudizio, è di natura formale e quindi polivalente e polisignificativo secondo la molteplicità e varietà dei piani oggettuali che sono stati indicati. (...) Fin quando si fonda la metafisica sulla corrispondenza fra le due prime operazioni della mente coll'essenza e con l'esse, si resta ancora nella metafisica aristotelica della forma".

${ }^{47}$ Cf. PC, 52.

${ }^{48}$ Ver WIPPEL, John. "Metaphysics and Separatio in Thomas Aquinas". In: Metaphysical Themes in Thomas Aquinas, op. cit., p. 69-104; MARITAIN, Jacques. Distinguer pour Unir ou Les Degrés du Savoir. 5a ed. Paris: Desclée de Brouwer, 1946, p. 215-130; POSSENTI, Vittorio. Nihilism and Metaphysics: The Third Voyage, op. cit., p. 39-86; LIMA VAZ, Henrique C. de. EF III: FC, 283-342.

${ }^{49}$ Cf. EF VII: RM, 173-175, n. 5, n. 6, n. 9, n. 11 e n. 33.
} 
significata. No caso de Lima Vaz esta diferenciação de perspectiva nos conduz à seguinte afirmação: a realidade significada (prima intentio) tem primazia sobre a forma lógica (secunda intentio), manifestando o duplo teor metafísico da "presença inclusiva do Absoluto nos seres finitos e a sua transcendência radical expressa na tríplice causalidade: eficiente, exemplar e final" ${ }^{\prime 50}$. Naturalmente É. Gilson - e não Fabro- constitui a fonte mais importante na proposta de Lima Vaz em repensar a originalidade da "metafísica tomásica do esse". Fabro está longe de ser uma referência fundamental para Lima Vaz neste campo, mas cumpre observar o lugar comum de destaque da noção de participação nas leituras dos dois autores. Contra a "hermenêutica intensiva" de Fabro convém observar, em primeiro lugar, que em Lima Vaz o acesso ao esse ocorre através da afirmação do ser no juízo, sem o qual ficaria sem resposta o modo adequado de aquisição das espécies na gnosiologia de Tomás de Aquino. O papel da aquisição das espécies na estrutura da inteligência espiritual responde, assim, à pergunta pelo que inteligimos e não sobre aquilo que inteligimos. O reconhecimento da participação dos entes nas razões eternas, portanto, não suprime o caráter limitado do inteligir humano. O processo do conhecimento intelectual humano em Tomás de Aquino supõe um dinamismo no juízo, e que Lima Vaz adequadamente reconhece, ao seguir neste ponto a interpretação de Joseph Maréchal ${ }^{51}$. Em vista da problemática levantada por Tomás de Aquino sobre como compatibilizar a luz intelectual em nós (lumen intellectuale in nobis) com a exigência das espécies inteligíveis recebidas das coisas (species intelligibiles a rebus acceptae), importa rever, pois, o que vimos na análise do artigo $5^{\mathrm{o}}$ da $84^{\mathrm{a}}$ questão: "não temos notícia das coisas materiais apenas pela participação nas razões eternas" (seção 1.1). Considerada na forma de uma leitura desta questão, Cornelio Fabro apresentaria uma concepção unilateral e não plenamente desenvolvida da noção de participação em Tomás de Aquino. Noutras palavras, Fabro não superou o horizonte de compreensão da Escolástica ${ }^{52}$.

Em que sentido podemos falar, portanto, de uma ampliação de inteligibilidade da noção de participação em Tomás de Aquino, à luz da interpre-

${ }^{50}$ EF VII: RM,185-186. Ver, em particular, a referência de Lima Vaz às "páginas clássicas de Fabro": EF VII: RM, 186, n. 33.

${ }^{51}$ Sobre o alcance metafísico do conhecimento intelectual humano, ver também os seguintes textos de Lima Vaz, considerados aqui como complementares e que orientam, em larga medida, nossa própria pesquisa: EF VII: RM, 223-237 e TMC, 430-437.

${ }^{52}$ Ele inclusive deformou o pensamento de Rahner a respeito do seu sentido de transcendência. Cf. SA. Não percebeu, em nível ontológico, o alcance da transposição do compreender epistemológico para o ser que compreende. Ele não assimilou o caráter ontológico da subjetividade como momento constitutivo para uma correta compreensão do Esse absoluto, movendo-se assim no horizonte da metafísica tradicional e sua índole ôntica. Seria necessário pensar o Esse absoluto enquanto dimensão abrangente, unidade entre subjetividade constituinte e o mundo constituído (como fazem E. Coreth e Lima Vaz), mas Fabro permanece vinculado à formulação objetivista da tradição escolástica, isto é, a uma formulação pré-moderna. 
tação proposta por Lima Vaz? Isto ocorre basicamente por sua audaciosa tentativa de repensar metodologicamente a própria concepção do subjectum da metafísica e, mais especificamente, a compreensão dos "dois caminhos da metafísica" (a via descensus e a via ascensus) - algo simplesmente impensável a partir de Cornelio Fabro.

[2] O duplo aspecto da metafísica da participação. O último livro de Lima Vaz, Escritos de Filosofia VII: Raízes da modernidade, embora permaneça algo exploratório se comparado aos dois conjuntos de obras sistemáticas, Antropologia Filosófica e Etica, pode ser considerado a justo título o seu testamento filosófico, e contém a síntese de seu pensamento no âmbito da Metafísica. De acordo com Lima Vaz a noção metafísica de participação é um dos eixos de sustentação no itinerário da metafísica do esse de Tomás de Aquino ${ }^{53}$. Neste itinerário, uma vez estabelecida a estrutura propriamente metafísica do ser finito, conceitualizada na relação esse-essentia, a questão agora seria a da maior inteligibilidade dessa relação, na medida em que o ser finito se refere "transcendentalmente à Inteligência e à Liberdade do Esse infinito" 54 . Esta questão alcança um "estágio verdadeiramente crucial" justamente ao tematizar o conceito fundamental de participação. Não é nossa intenção traçar aqui os diversos estágios do itinerário da metafísica do esse, segundo Lima Vaz. Importa neste ponto apenas considerar que, no itinerário da metafísica do esse, a questão sobre a participação permanecerá inassimilável para quem desconsidera a concepção do subjectum da metafísica por Tomás de Aquino em sua correlação com as noções transcendentais e a transcendência do Esse absoluto. Lima Vaz destaca as noções transcendentais Verum-Bonum no contexto das razões eternas ao correlacionar essas noções à Inteligência e à Vontade do Esse divino ${ }^{55}$. Os seres finitos se desdobram como verdade e bem, e, neste sentido, participam da Verdade e do Bem como Primeiro Princípio (Esse subsistens). Neste caso, o tema da participação diz respeito tanto ao problema da origem do ser finito (criação), quanto à questão acerca da ordem do universo. $O$ próprio Esse divino permanece a causa transcendente e inefável dos seres finitos. É sob essa perspectiva que, para Lima Vaz, Tomás de Aquino articula uma singular convergência temática em relação a Agostinho no que se refere à metafísica das Ideias e à noção de participação (exemplarismo). $\mathrm{Na}$ versão de Tomás de Aquino, há uma participação formal dos seres no Ser enquanto noção universalíssima (ens commune, o subjectum da metafísica), e uma participação causal dos seres, que existem concretamente em Deus como Esse infinito, absolutamente transcendente. A divergência em relação a Agostinho ocorre no plano gnosiológico, na medida em que este vincula o conhecimento das Ideias pela mente humana ao lumen intelligi-

\footnotetext{
${ }^{53}$ Para uma análise sintética sobre a noção metafísica de participação em Tomás de Aquino, segundo a perspectiva dialética da metafísica do esse, ver EF VII: RM, 171-191.

${ }^{54}$ Cf. EF VII: RM, 172.

${ }^{55}$ Cf. EF VII: RM, 178.
} 
bile diretamente comunicado a partir de Deus (por ex., Conf. XII, 25, 3) ${ }^{56}$. Este é o ponto central da discussão, que Lima Vaz situa precisamente no texto clássico da Suma de Teologia, Ia, q. 84, a. 5 e que remete ao De Ideis de Agostinho ${ }^{57}$. De fato, a breve questão $46^{\underline{a}}$ De Ideis, do livro De diuersis quaestionibus 83, de Sto. Agostinho ${ }^{58}$, teve uma importância capital na formação da teologia escolástica e em particular naquela de Tomás de Aquino ${ }^{59}$. Para sua leitura do texto de Tomás de Aquino Lima Vaz segue aqui a primeira parte da "recente e notável tese de Vivian Boland" Tomás de Aquino procura integrar a concepção aristotélica do nous (De Anima, III, c. 4) a uma metafísica das razões eternas: o lumen intelligibile é atribuído ao intelecto agente (nous poietikós), que do sensível abstrai o inteligível. Para Tomás de Aquino, a participação da mente humana na luz inteligível das razões eternas ocorre pela mediação do lumen naturale. A via descensus da metafísica do esse parte da intuição do Absoluto, como constitutiva da afirmação do ser no juízo (através do argumento de retorção contra a dúvida cética, que legitima o ponto de partida da metafísica) e que será expresso nas noções transcendentais; a via ascensus, por sua vez, tem como ponto de partida a apreensão imediata do ser no mundo sensível e se eleva à universalidade do ente enquanto ente (ens commune). O Absoluto como Ipsum Esse subsistens está implicado na afirmação protológica do ser no juízo (segundo o círculo da pré-compreensão do Absoluto). A afirmação judicativa tem como mediação a intuição do esse como ato perfeito na separatio, de acordo com J. Maréchal. Com isso Lima Vaz está propondo (além da via resolutionis como método normal da metafísica) o uso da via compositionis em chave dialética em acordo com a estrutura teórica da metafísica do esse em Tomás de Aquino, estrutura esta que opera segundo o tríplice movimento: (a) um movimento de negação da perfeição limitada dos seres finitos - isto é, a radical insuficiência do sensível- em

\footnotetext{
${ }^{56}$ EF VI: OH, 77-87. Tomás de Aquino articula a teoria agostiniana da iluminação com a noção aristotélica de inteligência ativa. Cf. AF I, 258; 282, n. 123.

${ }^{57}$ Cf. EF VII: RM, 174, n. 10.

${ }^{58}$ Para uma discussão sobre o De Ideis de Agostinho, ver V. BOLAND, Ideas in God according to Saint Thomas Aquinas: sources and synthesis, Leiden/New York/Köln: Brill, 1996, p. 38-42. Há traduções para o português deste texto. Cf. AGOSTINHO DE HIPONA, "Sobre as Idéias". In: Cadernos de Trabalho CEPAME II (1/1993) 5-11; “Das Idéias". In: Scintilla 5 (1/2008) 181-183. ${ }^{59}$ STh Ia, q. 15, a 1 sed contra; a 2 sed contra; a 3 sed contra; q. 84, a 5. Ver também EF VII: RM, 229.

${ }^{60}$ Cf. EF VII: RM, 174. A obra de Vivian Boland, Ideas in God according to Saint Thomas Aquinas: sources and synthesis, está dividida em duas partes. A primeira parte examina as fontes antigas, platônicas e neoplatônicas sobre a teoria das ideias eternas até sua transposição para a teologia cristã no Pseudo-Dionísio e em Santo Agostinho, além de percorrer a formação da tradição aristotélica em confronto com as Ideias. A segunda parte da obra do Fr. V. Boland (OP) trata propriamente da síntese de Tomás de Aquino, isto é, da posição de Tomás de Aquino acerca da teoria das Ideias e sua relação com Aristóteles e Agostinho. Para uma releitura do tema da pluralidade das Ideias na unidade da Inteligência divina, e que se beneficia da tese de V. Boland, ver também EF VII: RM, 105-109. Para um confronto com a interpretação de V. Boland, ver WIPPEL, John. "Thomas Aquinas on the Divine Ideas". The Etienne Gilson Series 16. Toronto, 1993.
} 
sua inadequação para responder às exigências de explicação do inteligível. Além disso, (b) um movimento de afirmação através do dinamismo inscrito na posição do ser no juízo: há uma superação (excessus) dos limites conceituais que podem ser apreendidos pela inteligência dos seres finitos (ens commune) e que (c) conduz à causalidade transcendente do Absoluto como causa eficiente criadora do conteúdo real do ens commune. É a partir desta estrutura que podemos pensar, segundo Lima Vaz, a participação vertical que vai de Platão a Tomás de Aquino: há uma hierarquia ontológica em cujo topo encontra-se a radical transcendência do Absoluto, seja como Bem (Platão), como Uno (Plotino), como Verdade (Agostinho), seja como Esse subsistens (Tomás de Aquino) ${ }^{61}$.

Lima Vaz parece aceitar, em relação ao "método lógico-dialético" (que nele se desenvolve mais a partir de Platão - o "gênio tutelar da dialética"- do que regrado estritamente a partir da Lógica de Hegel), algo semelhante à postura de J. Maréchal. Este diz não ser o método transcendental necessário (constitutivo) para o estatuto da metafísica, exceto culturalmente, isto é, em face da cultura filosófica contemporânea. Entretanto, admitida essa semelhança, com isso não ficaria claro até que ponto a "reviravolta linguística", ocorrida no século XX, poderia ser assimilada estruturalmente à releitura da metafísica do esse em Tomás de Aquino. A mediação linguística permaneceria desnecessária na releitura da metafísica? Em todo caso, como vimos, Lima Vaz tem plena consciência da pré-compreensão do Absoluto no círculo que marca a "oposição fundamental entre finito e infinito" 62.

\section{Metafísica do conhecimento finito e a pergunta pela participação nas razões eternas.}

[1] Hermenêutica e metafísica do conhecimento. Há proximidade e analogias entre o pensamento de Lima Vaz e a postura do "tomismo transcendental", sobretudo com Maréchal e Lotz, mas não há em Lima Vaz referências à necessidade estrutural de assunção do método para atingir e desenvolver o discurso metafísico, como ocorre explicitamente em Rahner e Coreth. Para este último, em especial, a metafísica só é possível com base em uma hermenêutica da existência humana no mundo e na história, na medida em que nos permite compreender a mediação (ratio) da imediatez (intellectus) do ser. Entretanto, a hermenêutica como doutrina da compreensão, por sua vez, só é possível transcendendo-se na direção da metafísica. É neste sentido que pressupomos aqui uma relação essencial entre hermenêutica e metafísica do esse. A ontologia da compreensão permanece implicada

\footnotetext{
${ }^{61}$ Cf. EF VII: RM, 188.

${ }^{62} \mathrm{MD}, 15$.
} 
na metodologia da interpretação, como o trabalho de pensamento que consiste em discernir o sentido escondido no sentido aparente, segundo o "círculo hermenêutico" que Heidegger nos ensinou a trilhar. Com isso não seria permitido pensar uma correlação entre hermenêutica e metafísica do esse, de tal modo a explicitar, na dialética da participação, uma vertente hermenêutica na própria estrutura metafisica do ser finito ${ }^{63}$ ?

Para Karl Rahner, a oposição entre Agostinho e Tomás de Aquino não se situaria entre o caráter a posteriori puro do conhecimento em Tomás de Aquino e a visão das ideias de Deus em Agostinho (um apriorismo de ideias objetivas). Rahner entende que há em Tomás de Aquino a afirmação, no homem, do lumen intellectus como "participata similitudo luminis increati", concebida como "a priori formal" (eines formalen Apriori), consciente apenas na pré-compreensão (Vorgriff) do $\mathrm{Ser}^{64}$. O significado proposto por Rahner dessa expressão nada tem de uma leitura kantiana dos textos de Tomás de Aquino. Isto nos parece verdadeiro, mesmo considerando que, no todo de sua "metafísica do conhecimento finito", Rahner preserve dicotomias de matriz kantiana (como sensível e inteligível, sujeito-objeto) que não podem ser atribuídas a Tomás de Aquino. Nisto Karl Rahner mostra não ter apreendido o que talvez seja o mais importante passo da perspectiva existencial presente em Sein und Zeit, de Martin Heidegger: a superação da distinção entre os polos dicotômicos, sobretudo no que se refere à oposição entre subjetividade e objetividade, oposição esta que marca e compromete o todo da investigação de Rahner. Na introdução de Sein und Zeit Heidegger cita Tomás de Aquino, para falar a respeito da abertura do espírito à totalidade do ente: "anima nata est convenire cum omni ente/ est quodammodo omnia". O que Heidegger entende pelo primado ôntico-ontológico da "presença", em nossa opinião, não é incompatível com a intenção de Tomás de Aquino, que aponta para aquilo que é previamente constitutivo (saber atemático) na própria fundamentação da totalidade dos entes. Daí o primado da "presença", o ente privilegiado que tematiza o sentido de ser. De modo análogo à "virada" heideggeriana, Rahner posteriormente supera um ponto de vista estritamente antropocêntrico-transcendental acerca do primado da subjetividade do ente/ser humano

${ }^{63}$ Para um confronto, ver MD, 15.

${ }^{64}$ Cf. K. RANHER, Geist in Welt: Zur Metaphysik der endlichen Erkenntnis bei Thomas Von Aquin, Ed. J. B. Metz, München, 1957, p. 389-390. Cf. STh. Ia, q. 12, a 11 ad 3; q. 85, a 5; q. 88, a 3 ad 1. Estes textos, segundo Rahner, caracterizam o lumen como princípio de todo conhecimento, pois já que não há conhecimento sem "antecipação" (Vorgriff) do esse, então a afirmação implícita do ser absoluto é a condição de possibilidade de todo conhecimento. Sobre a influência de J. Maréchal em K. Rahner, ver NEUFELD, Karl-Heinz. „Maréchal et Rahner". In: GILBERT, Paul (Org.). Au Point de Départ: Joseph Maréchal entre la critique kantienne et $\mathrm{l}^{\prime}$ ontologie thomiste, Bruxelles: Lessius, 2000, p. 427-446. Ver também SPRUIT, Leen. Species Intelligibilis: From perception to knowledge. Vol. I, Classical roots and medieval discussiones. Leiden: E. J. Brill, 1994, p. 156-174. Para um breve mas significativo balanço crítico do "tomismo transcendental", ver PUNTEL, B. Lorenz. Ser e Deus: Um enfoque sistemático em confronto com M. Heidegger, É. Lévinas e J. -L. Marion, op. cit., 62-63. 
e passa a considerar o horizonte prévio da autocomunicação de Deus. Emerich Coreth dá um passo além e elaborou, na esteira de Rahner, uma exposição sistemática da metafísica cristã tradicional. Ele segue Heidegger e Rahner no deslocamento da preocupação sobre a estrutura do juízo para uma discussão centrada na estrutura da pergunta, como ponto de partida da metafísica e como problematização sobre o sentido de ser ${ }^{65}$, isto é, o ser enquanto horizonte da pergunta (Das Sein als Horizont der Frage) ${ }^{66}$. O fenômeno total do mundo - enquanto mundo humano da experiência e compreensão - permanece como a limitação estrutural de nossa pergunta pelo sentido. Mas, pela pergunta, ultrapassamos constantemente nosso mundo. O que devemos compreender por "sentido" percorre um grande arco de problemas que envolve a filosofia da linguagem e a metafísica, e o uso do termo que pressupomos desde o início (seção 1.2) tem uma acepção especulativo-hermenêutica próxima a de Lima Vaz, que distingue duas acepções na polissemia do termo "sentido": a acepção lógico-linguística e a acepção existencial. A primeira diz respeito à estrutura semântica da linguagem (enquanto esta se apresenta como corpo significante), cuja evolução histórico-conceitual, em contexto filosófico moderno, desemboca na primazia da representação (esse objectivum) sobre o ser, característico de grande parte da filosofia da linguagem que se estrutura no século XX. Em contraste, a segunda acepção de sentido preserva a amplitude analógica do ser e concebe a inteligibilidade do objeto de acordo com o vetor teleológico no qual ele se situa na compreensão e na linguagem do sujeito. Esta segunda acepção vai além do campo neutro (ou pretensamente neutro) da acepção lógico-linguística de sentido e penetra de forma decisiva no terreno existencial do sujeito, pois está essencialmente orientada para os fins que ele se propõe em sua abertura intencional e o conduz ao esse como conteúdo significado da linguagem ${ }^{67}$. No modo como compreendemos o problema do sentido será possível observar uma complementaridade de perspectivas, hermenêutica e metafísica, na fenomenologia da iluminação da inteligência criada por Deus, tal como Tomás de Aquino vê exprimir-se em Agostinho, ao formular uma noção filosófico-antropológica do homem como imago Dei, que une temáticas de origem bíblica e platônica (seção 1.1). Daí preferirmos falar não em acepção existencial de sentido, mas em acepção especulativo-hermenêutica, a partir de um deslocamento teórico para o que vem a ser a essência e a estrutura da pré-compreensão (seção 1.2), na relação de con-

\footnotetext{
${ }^{65}$ Cf. CORETH, Emerich. Questões Fundamentais de Hermenêutica, op. cit., p. 169-170. Cf. EF III: FC, 154-160.

${ }^{66}$ Cf. CORETH, Emerich. Metaphysik: Eine methodisch-systematische Grundlegung, op. cit., p. 120-131.

${ }^{67}$ A identidade intencional do ato do sujeito e do ato do objeto foi transformada por Tomás de Aquino em sua recepção do axioma enunciado por Aristóteles (De Anima, III, 2, 425 b 26): "O intelecto no seu ato é o inteligível no seu ato" (Intellectus in actu est intellectum in $a c t u)$. Este é, de acordo com Lima Vaz, "o fundamento noético da doutrina do sentido na sua acepção existencial, caracterizada pela primazia do ser, e que perdurará até o século XIV.". Cf. EC III: FC, 160.
} 
dicionamento entre o mundo e o ser. O problema da linguagem fica sempre sendo uma questão que se apresenta por trás do problema hermenêutico ${ }^{68}$. Entretanto, consideramos indispensável ressaltar que não tomamos as duas acepções de sentido (lógico-linguística e especulativo-hermenêutica) como excludentes, mas sim como complementares. A dicotomia entre subjetividade/objetividade é falsa, mas devemos reter o caráter científico de nossas asserções, isto é, não podemos inventar fatos: ao contrário do que pretende a linha proposta por Gadamer, o método hermenêutico não precisa negar a objetividade científica ou um caráter objetal para a noção de verdade. $\mathrm{O}$ aspecto hermenêutico de sentido supõe e integra o aspecto analítico. É, portanto, sob a perspectiva de uma abordagem especulativo-hermenêutica do problema da participação nas razões eternas que tratamos algumas linhas gerais de comparação entre Cornelio Fabro e Lima Vaz (seção 2).

[2] O itinerário do espírito humano e a dialética da participação nas razões eternas. Fabro e Lima Vaz partem de pressupostos diferentes quando se aproximam da obra de Tomás de Aquino. É possível ver aqui um "conflito de interpretações", e Géry Prouvost teria razão, portanto, quando diz que a relação de fidelidade ou de infidelidade entre Tomás de Aquino e os "tomismos" é uma decisão tanto histórica quanto filosófica ${ }^{69}$. Mas disto não decorre, como pretende Prouvost, que os conflitos hermenêuticos tenham seu fundamento necessariamente nos próprios textos de Tomás de Aquino. Em todo caso, o compromisso com a tradição filosófica que provém de Heidegger supõe um tipo de concepção de ser que Fabro não está de modo algum disposto a aceitar. É claro que uma decisão sobre a "fidelidade a Sto. Tomás" iria supor que poderíamos, com toda clareza, distinguir as pré-compreensões legítimas das ilegítimas. Mas essa é uma questão, poder-se-ia dizer, eminentemente hermenêutica, que escapa à crítica de Fabro precisamente por ele já se situar em um determinado horizonte de compreensão. Entretanto, e este é um aspecto ainda mais importante da questão, não deveríamos exagerar o alcance da "fusão de horizontes", a ponto de negarmos o caráter objetivo da verdade, algo que amiúde se observa na tradição hermenêutica ${ }^{70}$. A redescoberta da originalidade da

\footnotetext{
${ }^{68} \mathrm{Na}$ trilha aberta por Heidegger, já em Ser e Tempo, a concepção de linguagem fundamenta-se na compreensão existencial-ontológica e histórico-hermenêutica da existência. A linguagem era vista como constitutiva do Dasein, como ser-no-mundo. O Heidegger posterior se ocupou mais intensa e profundamente com o problema da linguagem. De modo mais profundo ele passa a conceber a linguagem a partir do ser, superando assim o domínio da subjetividade. Por outro lado, como observa E. Coreth, nesta nova etapa ocorre conjuntamente um estreitamento em sua concepção de linguagem. Ele estreita sua própria concepção ao falar de modo mítico, obscuro, hipostasiando a linguagem na direção de uma poética evasiva. Cf. CORETH, Emerich. Questões Fundamentais de Hermenêutica, op. cit., p. 30-31.

${ }^{69}$ Cf. G. PROUVOST, Thomas d'Aquin et les thomismes, Paris: Éditions du Cerf, 1996, p. 15.

${ }^{70}$ Sobre as críticas de Coreth a este aspecto da tradição hermenêutica, ver CORETH, Emerich. Questões Fundamentais de Hermenêutica, op. cit., p. 149s. Ver também Metaphysik: Eine methodisch-systematische Grundlegung, op. cit., p. 342s. No que se refere a Prouvost, por sua vez, a distinção entre interpretação e verdade - se é que para ele isto é possível- não é clara.
} 
concepção de esse em Tomás de Aquino foi posta no centro de um debate que permanece atual, a saber: a crítica de Heidegger de que toda a metafísica ocidental seria um pensar baseado no "esquecimento do Ser". Mas, ao contrário do que Heidegger entende em relação ao pensamento ontoteológico, a metafísica de Tomás de Aquino não presume integrar Deus em um sistema explicativo de realidades no seu todo. Ao contrário, Tomás aponta para o Mistério absoluto e inacessível, que parte do ente finito para algo que está acima de qualquer razão, isto é, Aquele que está acima de tudo o que pode ser compreendido por nossa mente (seguindo aqui, ao menos até certo ponto, os passos de Dionísio). Entretanto, para além do que literalmente possamos constatar em seus textos, há em Tomás de Aquino algum conhecimento positivo de Deus (embora permaneça em geral apenas implícito); por isso, o coroamento da metafísica não é a rigor uma teologia apofática. Não há, aliás, nada de contraditório na afirmação de que sabemos que Deus é, mas não sabemos o que Ele é. Na linha proposta por Tomás nunca será demais insistir que Deus não pode ser concebido como razão suficiente do mundo. O subjectum da metafísica não é Deus, mas o ens commune. Entretanto, Deus é concebido como causa ou princípio, inatingível em si mesmo pela razão humana, embora possamos partir de seus efeitos para chegarmos de algum modo até ele, como fundamento da realidade humano-mundana ${ }^{71}$. A doutrina da participação é, portanto, um componente essencial da concepção de metafísica em Tomás de Aquino. Não há, é claro, um tratado específico de Tomás de acerca desse tema, mas podemos destacar a relevância específica deste tópico para discutir o problema mais amplo acerca da relação entre a dimensão absoluta do ser (esse per se subsistens) e a dimensão contingente dos entes (finitos). Pensar essa relação nos faz aqui apenas apontar para o quadro teórico de retomada da clássica "questão do ser" e também com o que devemos entender por "Deus", no contexto da metafísica de inspiração cristã. Se é verdade que, em Tomás de Aquino, a conceitualidade oriunda de Aristóteles permanece problemática (por exemplo, sua noção de substância e de atributos), e em certo sentido se torna um obstáculo à explicitação de um sentido pleno de ser (Ipsum esse subsistens), não podemos esquecer também os problemas inerentes ao fato de que Tomás assume o esquema platônico da participação para explicar o ente finito e sua diferença para com o infinito. Daí as várias questões, em Tomás de Aquino, que estão vinculadas à recepção da noção de participação a partir da tradição neoplatônica e suas implicações ontológicas: a problemática da transcendência de Deus, sua incompreensibilidade, o estatuto da teologia negativa, a doutrina da analogia etc. Estivemos argumentando, desde o início (seção 1.1), que em Tomás de Aquino o conhecimento de Deus ocorre a partir das perfeições das criaturas que dele procedem, e que devemos distinguir dois aspectos nos nomes atribuídos a Deus: o modo de significar (modus significandi) e

${ }^{71}$ Cf. STh. Ia, q. 45 , a. 6 ; q. 105 , a. 5. 
a coisa significada (res significata), e, precisamente neste caso, a perfeição divina, a fonte eminente das perfeições. A relação das criaturas à perfeição desta fonte ocorre per participationem. É preciso insistir, portanto, sobre a distinção entre perfectio e modus significandi. No que se refere à noção de perfectio, central no pensamento de Tomás de Aquino, há uma aporia na passagem das imperfecta (modi finiti da perfectio) para a perfectio absolute: como assimilar o modo finito de realização da perfeição se não há algum conhecimento prévio dessa perfeição? Como vimos anteriormente (seção 1.2), já sempre pressupomos o conhecimento da perfectio no itinerário do espírito humano para Deus. Uma questão adicional consiste em interpretar de modo mais refletido a relação entre as perfectiones das criaturas e o possível significado de perfectio absolute em Tomás de Aquino ${ }^{72}$. No processo do conhecimento intelectual humano há um círculo que permaneceu impensado em Tomás de Aquino, mas que, em contextos posteriores, tornou-se problema central, como em Hegel e Heidegger. A leitura de Fabro acerca da participação nas razões eternas simplesmente ignora o problema (ou o deturpa) sob a alegação de idealismo ${ }^{73}$. $\mathrm{O}$ temor e tremor diante da pecha de idealismo no pensamento de Tomás de Aquino (e, por consequência, a negação da real transcendência de Deus), faz com que Fabro, entre outras motivos, recuse o papel central do juízo na afirmação do ser. De sua parte Lima Vaz tem plena consciência do problema da transcendência, e, em suas observações críticas (embora dispersas) à "metafísica da subjetividade" de $\mathrm{Hegel}^{74}$, aponta para a fundamental diferença entre o Absoluto formal (noções transcendentais) e o Absoluto real (Ipsum esse subsistens): para evitar uma "transcendência ruim", um "mau infinito", segundo os termos hegelianos, a perfectio reside em certo sentido fora do movimento do itinerarium mentis in Deum, pois conhecemos apenas que Deus é, mas não $o$ que Ele é (Absoluto real). No confronto com o pensamento moderno, em especial com Hegel, há intérpretes de Tomás de Aquino que sempre assumiram uma atitude crítica acerca do processo de imanentização do Ser no pensar, de tal modo a preservar a transcendência de Deus ${ }^{75}$. Este é

${ }^{72}$ Cf. De pot. q. 7 a. 5. Para uma discussão noutra perspectiva ver PUNTEL, Lorenz B. Em busca do objeto e do estatuto teórico da filosofia: Estudos críticos na perspectiva histórico-filosófica, op. cit., p. 39-131.

${ }^{73}$ Fabro reconhece que a noção de participação constitui uma superação (Aufhebung, em sentido hegeliano) da oposição entre Platão e Aristóteles. Entretanto, ele crítica de modo indiferenciado o que considera uma confusão dos intérpretes de Tomás de Aquino, que seguiriam o a priori de Kant com base na experiência e na apreensão do ser no ato do juízo (J. Maréchal, Lotz, Rahner, Metz). Cf. IH, 470. Esta má compreensão do que se propõe o "tomismo transcendental" está conectada a sua reação crítica ao pensamento moderno, sobretudo no que se refere à teoria do Absoluto de Hegel e à ontologia fundamental de Heidegger. Não parece surpreendente que Fabro, após a publicação de suas obras sobre a doutrina metafísica da participação em Tomás de Aquino, retroceda filosoficamente na direção de um diálogo privilegiado com o existencialismo de Kierkegaard.

${ }^{74}$ Cf. EF III:FC, 220, 246 e 307.

${ }^{75}$ Sobre a problemática da imanência do Ser no pensar, de tal modo a preservar uma adequada perspectiva realista sobre o conhecimento humano, ver especialmente CORETH, Emerich. Metaphysik: Eine methodisch-systematische Grundlegung, op. cit., p. 148-149. 
um importante ponto comum a Fabro e a Lima Vaz, em suas versões da "dialética da participação". Em confronto com as duas leituras, esboçamos uma reflexão transcendental - na perspectiva de uma teoria transcendental do Absoluto- sobre os limites do conhecimento intelectual humano acerca das razões eternas de Deus, nos marcos de uma hermenêutica filosófica aberta à metafísica. Esta reflexão pretende se manter a meio caminho entre versões racionalistas e irracionalistas de interpretação da metafísica do conhecimento de Tomás de Aquino.

\section{Conclusão}

Resumimos os principais passos do caminho percorrido nas seguintes teses:

1) A análise do artigo $5^{\mathbf{o}}$ da $84^{\mathrm{a}}$ questão da Primeira Parte da Summa theologiae de Tomás de Aquino revela, pelo menos, dois aspectos interconectados: (a) De acordo com a via platonica da perspectiva agostiniana, no intelecto humano há uma participação da luz divina em nós. (b) Mas isto, acentua Tomás de Aquino, ainda não é propriamente conhecer o ser de Deus: ter por participação a luz intelectual não seria suficiente para uma formulação adequada do processo do conhecimento intelectual humano, que recorre, necessariamente, às species intelligibiles recebidas das coisas materiais. Há uma releitura de Tomás de Aquino acerca do modo como Agostinho concebe as razões eternas.

2) Não há um exclusivo conhecimento negativo de Deus (conhecimento não-quididativo) em Tomás de Aquino. Mas um conhecimento positivo de Deus permanece em geral apenas implícito e não desenvolvido. É permitido falar de uma aporia no pensamento de Tomás de Aquino, por este não reconhecer em nosso acesso a Deus um "círculo de compreensão" no próprio processo de conhecimento intelectual humano.

3) Para além do que historicamente podemos constatar no texto medieval, acreditamos ser possível falar, sob perspectiva hermenêutica, de um dinamismo transcendental do espírito em nosso acesso às razões eternas. Há uma pressuposição do Absoluto no conhecimento do ser humano como espírito no mundo.

4) Cornelio Fabro e Lima Vaz têm em comum o reconhecimento da via platonica na transposição do exemplarismo de Agostinho na obra de Tomás de Aquino. Ambos destacam a importância constitutiva da noção metafísica de participação na redescoberta da originalidade do actus essendi. Todo ser criado é, em certo sentido, uma participação nas ideias eternas de Deus. Esta noção é pensada a partir da causalidade transcendente do ser como Ipsum Esse subsistens. Mas as duas leituras representam interpretações divergentes sobre o modo como Tomás de Aquino concebe nosso acesso às razões eternas. 
5) A obra de Cornelio Fabro assinala um momento decisivo na redescoberta do papel da participação no pensamento metafísico de Tomás de Aquino. Mas Fabro se mantém no horizonte ôntico de sentido da Escolástica tradicional, e não reconhece o papel fundamental do juízo negativo na teoria do conhecimento de Tomás de Aquino. Em consequência, o acesso às razões eternas supõe um "recurso a Deus" de modo irrefletido, sem pensar o papel de mediação da subjetividade e a dimensão originária entre subjetividade e objetividade.

6) Lima Vaz reconhece adequadamente a necessidade de repensar a própria estrutura metódica de nosso acesso ao Absoluto. Ele reconhece o dinamismo intelectual da afirmação do ser através do juízo e repensa em chave dialética o subiectum da metafísica em Tomás de Aquino. Há uma participação vertical dos entes no Esse absoluto e o tópico das razões eternas alcança uma amplitude radical em sua tematização da "metafísica da Ideia em Tomás de Aquino". Mas não parece suficientemente claro se Lima Vaz assume, do ponto de vista estrutural, a "reviravolta linguística" da filosofia contemporânea, com suas implicações críticas à pretensão excessiva da Razão, inscrita na conceitualidade lógico-dialética.

7) No conflito das interpretações entre as duas leituras, optamos por Lima Vaz, mas propomos, a partir de nossa própria concepção, um enxerto hermenêutico em sua "dialética da participação", isto é, um maior acento na pergunta pelo sentido do ser. Disto resulta a proposta, naturalmente aqui apenas esboçada, de uma metafísica do conhecimento finito que pretende conciliar hermenêutica e "metafísica do esse".

No clima filosófico atual, que se pensa pós-metafísico, a retomada da discussão sobre as razões eternas, à luz de Tomás de Aquino, oferece um interesse não apenas histórico. Diversos passos intermediários não foram contemplados aqui. Mas esta discussão levanta problemas que se relacionam com a "questão de Deus" como um programa mais amplo de pesquisa, de um modo estranho às duas principais correntes contemporâneas que tratam do assunto: o pensamento judaico-cristão pós-moderno, que privilegia um discurso apofático de Deus, e uma filosofia analítica da religião, cuja primazia lógico-linguística do discurso torna em geral inassimilável a pergunta pela participação da totalidade dos entes nas razões eternas de Deus.

Endereço do Autor:

Rua Cabral Veras, 550

Maraponga

60711-530 Fortaleza - CE

lcarlossousa@hotmail.com.

Síntese, Belo Horizonte, v. 48, n. 151, p. 327-355, Mai./Ago., 2021 